International Journal of Applied Linguistics \& English Literature

ISSN 2200-3592 (Print), ISSN 2200-3452 (Online)

Vol. 1 No. 3; July 2012 [Special Issue on World Literature in English]

\title{
Questioning V.S. Naipaul's Flawed World in The Mystic Masseur and $A$ Bend in the River
}

\author{
Indrani Ramachandran \\ Universiti Putra Malaysia, Malaysia \\ Rohimmi Noor \\ Universiti Putra Malaysia, Malaysia
}

Received: 10-07- 2012

Accepted: 25-07- 2012

Published: 31-07- 2012

doi:10.7575/ijalel.v.1n.3p.15

URL: http://dx.doi.org/10.7575/ijalel.v.1n.3p.15

\begin{abstract}
Acknowledged as one of the world's finest writers in the English language, V.S. Naipaul's cynicism has, over the decades, come to represent his very identity as a writer, so much so that any discussion about Naipaul's brilliance as a writer almost always finds itself addressing his penchant for controversies that conspicuously come across in almost all his written works. This paper will explore such a negative stance taken by V.S. Naipaul towards Third World countries and people, namely Trinidad and Africa, as featured in his two works of fiction, The Mystic Masseur and A Bend in the River and, in the process, attempt to understand the reasons behind his doing so. Through the application of the concept of Nihilism, this paper shows that people in the two countries in question have an inherent sense of futility in them, and that Naipaul's portrayal of them in a negative light is indeed based on these realities that he saw and experienced.
\end{abstract}

Keywords: human flaws, humour, Nihilism, Trinidadian Indians

\section{Introduction}

V.S. Naipaul is a cynical man. To him, the society that he writes about offers a gloomy vision, and he is content with presenting to his readers that reality that he sees, gloominess and all. In an article that appeared in The Sunday Times in 2007, Appleyard said the following of Naipaul, "Naipaul is hypersensitive to human flaws. He (Naipaul) once said: "I was gifted at an early age - the minute I saw a person, I could see the flaw in that person. It was like a curse" (Appleyard).

This ability to satirise human flaws and present them in writing in a most engaging yet matter-of-fact manner has, over the decades, helped shape Naipaul's success as one of the greatest writers in the English language. Alternately, the controversies that Naipaul has created in the process have also earned him a great deal of animosity among critics and fellow literary figures because Naipaul is not a man who minces his words when it comes to speaking up, or writing about the ugly realities of the world as he sees them. What he sees is what he portrays in his writings. Therein lies the controversy.

The opening line of an article by Thieme (1987) entitled Searching for a Centre: The Writing of VS Naipaul which reads, "Few writers arouse more controversy than V. S. Naipaul" (1352), clearly underlines the impervious connection between Naipaul, the incredibly intelligent writer and Naipaul, the cynical master of harsh yet acute observation. However, despite the negative reception that Naipaul has brought upon himself through his writings, one cannot help wonder if there is not in him a purveyor of truth that human society in general is still unprepared to come to terms with. Could it be that the truth that he sees and portrays in his writings is so overwhelming in conviction that we choose to deny it? Could it be that the world that he portrays in his novels is so nihilistic in nature, leaving Naipaul with no other option but to present it negatively because, in all its pessimism, the world that he sees is indeed full of flaws? In that context, is Naipaul's stand on the world being irredeemably flawed valid?

With these questions in consideration, this paper examines two fictional works of Naipaul, The Mystic Masseur (1957) and A Bend in the River (1979) and attempts to understand, through them, the extent to which Naipaul's perception of the flawed universe has permeated his writings, and if that perception is a result of his personal 
International Journal of Applied Linguistics \& English Literature

ISSN 2200-3592 (Print), ISSN 2200-3452 (Online)

Vol. 1 No. 3; July 2012 [Special Issue on World Literature in English]

distaste towards the world that he writes about, or if indeed the world itself is so steeped in Nihilism that Naipaul cannot but merely represent it as such through his fiction.

\section{V.S. Naipaul's Perception of Trinidadian Indians in The Mystic Masseur}

Almost all of V.S. Naipaul's earliest works of fiction use Trinidad as the setting with Trinidadian Indians as the chief subjects, and this trend has been apparent since his first published work, The Mystic Masseur.

The Mystic Masseur tells the story of Ganesh Ramsumair, a failed schoolteacher who decides to switch careers and become the village masseur based on the advice given by his aunt, who is referred to in the novel only as The Great Belcher. The Great Belcher convinces him so effectively that his vocation should rightfully be massaging people that he begins to believe that he could actually become a good masseur because "Pa was a good massager and I know all he did know" (The Mystic Masseur, 58), although in reality, Ganesh had never acquired the skills from his father. When his career as a masseur appears to slip into a lull, Ganesh begins contemplating on the idea of becoming a writer, again after being advised by The Great Belcher, who says, "a man like you should be doing something else...bookwork" (The Mystic Masseur, 58). Driven by his faith in The Great Belcher's words which merely reflects his confusion about what he is good at, Ganesh unwittingly says, "Yes, is that self I go do." A little bit of massaging and a little bit of writing." (The Mystic Masseur, 58) However, Ganesh fails as a masseur, but after much self-imposed delays and failures, finally succeeds in writing a book. Although the book does not initially gain popularity, Ganesh, being clever and cunning enough to manipulate his failed situations into opportunities, quickly finds himself transforming into a revered mystic, a thriving entrepreneur and, in later years, a famous politician.

One cannot help but wonder if the frivolities of the characters in The Mystic Masseur were a result of a lack of a constructive identity among Trinidadian Indians whose Indian roots they could only relate to through hearsay, and, as a result, were not able to connect with it with pride. This absence of a history that they could take pride in could have caused the lack of conviction that their lives appeared to revolve around. It is almost as if the characters featured in the novel were all ignorant about the importance of the larger things in life and, as a result, went about living their lives trivializing everything that they come across. Ganesh, for instance, believes that he can take up any profession according to his whims and fancies even though he is clearly aware that he has no experience or qualification whatsoever in the desired profession. It is almost as if in Trinidad, anyone can become anything provided they could find a way to. And this is the farcical attribute of the characters in The Mystic Masseur that Bates refers to in his 1963 article in London Sunday Times, "As Naipaul has said, you don't need to satirize some aspects of the West Indian scene, and he had to understate the farcical elements rather than exaggerate them." ("In a Derelict Land: The Novels of V.S. Naipaul", 74).

If one wishes to understand the reason behind the triviality of the characters in the novel, one must analyse the background of the society which formed its mindset. In his travel book, A Middle Passage, Naipaul describes the Trinidadian Indians as people who were "living in a borrowed culture" (64). Naipaul's stand on Trinidad Indians is that they lacked a constructive identity because they were brought in from India as indentured labourers and chose to stay on in Trinidad when the colonials left, and because the continuing generations had not had direct experience with the real India, and had "lived as people with the idea of acceptance" (The Writer's People, 77) with their lives "being simply one of those things" (The Writer's People, 77). The concept of fate comes into the picture in Naipaul's observation of the people living with an "idea of acceptance" (The Writer's People, 77), which Naipaul's tone of writing dismisses as a negative thing. When one becomes attuned to the "idea of acceptance" (The Writer's People, 77), the most natural way of living the life of an immigrant would be to accept all that comes their way and to not have much conviction about one's culture and individuality. With such a mindset, the Indian values that they had till then known become interspersed with the culture of their new homeland, and as generations pass, the issue of identity becomes more convoluted.

Sudan, a Trinidad-born writer and poet, wrote in his article entitled V.S. Naipaul Does Trinidad a Disservice, which was published in February 2011, "There is no doubting Naipaul's mastery of the English language and his ability to weave compelling narratives. But what becomes overwhelming when delving into the depths of his prose is a dark undercurrent of racism - an almost barefaced contempt for the people of his own country."

But is it really contempt that drives Naipaul to present Trinidad in a negative light? In order to answer the question as to why Naipaul consistently chooses to use Trinidadian Indians as the subjects of most of his novels despite his having made up his mind at the tender age of 14 to leave Trinidad, and despite claiming in an interview given to Bernard Levin in 1983 that he thought "it was a great mistake to have been born in Trinidad" (The World Is What It Is, xv), one must understand Naipaul's real sentiments towards Trinidad. The inability to

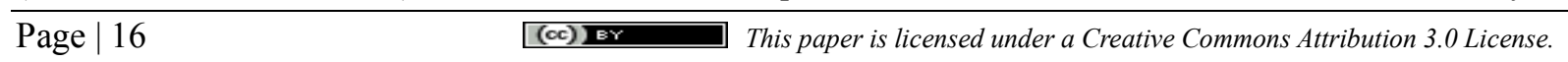


International Journal of Applied Linguistics \& English Literature

ISSN 2200-3592 (Print), ISSN 2200-3452 (Online)

Vol. 1 No. 3; July 2012 [Special Issue on World Literature in English]

feel connected to one's place of birth does not amount to lack of genuine concern for the place, and this is exactly the case with Naipaul.

Naipaul's personality as a writer could also have been imperceptibly shaped by the sense of degradation that he saw his father, Seepersad, go through, being forced to raise his family in the large house of his in-laws' extended family, when Naipaul and his siblings were young children. King aptly describes the impact of the traumatic environment on Naipaul. "This, and other periods of moving house and being at the mercy of others when living among relatives, resulted in Naipaul by the time he was fourteen creating a mask of superior aloofness and left him with a lasting preference for order, style, achievement and solitude" (King 5).

King goes on to write, "A severe critic of India and the shortcomings of the newly independent nations, he is also a nationalist who feels humiliated by the weakness and exploitation of the colonized" (King 2). It can be seen, therefore, that Naipaul does have genuine care for Trinidad and its people. However, being the master of irony and satire that he is, Naipaul expresses it in the only way he knows how - by mocking the Trinidadians into coming to terms with the bare truths about their decay, as he sees them. King writes on this aspect that "Naipaul's concerns with the decay of traditional Hindu Trinidad and the incongruities of its existence within a predominantly black, Westernised, national community of various cultures" (King 28) are the very factors that cause him to present Trinidad with "irony, comedy and absurdity" (King 28). To Naipaul, dark comedy is the best way to deeply project a message about a social predicament.

Naipaul himself has written in The Middle Passage about the role a writer must play for a country like Trinidad, possibly hinting that it was exactly that that he has been doing for Trinidad since his first book. "Living in a borrowed culture, the West Indian, more than most, needs writers to tell him who he is and where he stands" (The Middle Passage, 64). He goes on to say, "The insecure wish to be heroically portrayed. Irony and satire, which might help more, are not acceptable; and no writer wishes to let down his group...the Trinidadian expects his novels, like his advertisements, to have a detergent purpose" (The Middle Passage, 64).

The goal of a writer, according to Naipaul is the "pursuit of honesty, to react truly to situations, discovering the truth about it" (Jussawalla 1997). In an interview given to Levin, he said, "At an early age I thought of myself as a writer...it was something that was given to me as a fantasy of nobility, a fantasy of a good life, the beautiful life, the civilized life. I became a writer because of this overwhelming idea of its nobility as a calling" (Jussawalla 1997).

Naipaul's intention, therefore, is probably to tell the world about the reality that he witnessed in Trinidad, disregarding the fact that the Trinidadians might not be prepared to face the stark truths about themselves. The reality is that, there appears to exist among the Trinidadian Indians, a sense of futility which makes them resort to living their lives without any direction and conviction, accepting anything that comes their way in the name of pursuing success.

The question as to whether the fictionalised characters in The Mystic Masseur depict the real Trinidad, the answer to which will serve to defend Naipaul's stand in presenting Trinidad as a dark comedy, is answered in King's observations in his book.

Those familiar with Trinidadian history should recognise how Naipaul has used local events, characters and such politicians characters and such politicians as Uriah Butler, Albert Gomes, Arthur Cipriani and Naipaul's two uncles, Rudranath and Simbhoonath Capildeo in his novel. Naipaul's early fiction is based on memories of Trinidadian cultural and political life before he left for England in 1950. (King 29)

Hence, it can be clearly seen here that the story of Trinidad that Naipaul depicts in The Mystic Masseur is not merely a figment of his harshly-judgmental imagination. Instead, Naipaul has merely presented the world of Trinidad that he saw and knew to be real; a world which he saw to be laced with nihilistic tendencies.

What is interesting, though, is that, despite the mocking tone with which he depicts the main characters and settings of The Mystic Masseur, Naipaul appears to have a soft spot for characters like Ganesh, cunning and conniving though he is. It is as if "Naipaul has a Trinidadian delight in the con-man; he admires those who manage to succeed, those who seize the time and make use of opportunities" (King 30) which to Naipaul is "better than fail and make excuses" (King 31). Here lies Naipaul's irony. For while he laughs at Ganesh 


\section{International Journal of Applied Linguistics \& English Literature}

ISSN 2200-3592 (Print), ISSN 2200-3452 (Online)

Vol. 1 No. 3; July 2012 [Special Issue on World Literature in English]

Ramsumnair as he becomes G. Ramsay Muir, M.B.E., Naipaul also offers him sympathy and admires Ganesh for his persistence to rise above his situations, albeit in his own comical and frivolous ways.

\section{Naipaul's Representation of Africa in $\boldsymbol{A}$ Bend in the River}

$A$ Bend in the River is a widely discussed novel for its controversial representation of Africa. It is a novel which has brought upon Naipaul a great deal of criticisms, especially from post-colonial writers and critics. Although the African town that the protagonist Salim moves to remains unnamed throughout the novel, the striking resemblance of the novel's characters and events to a travel essay entitled A New King for the Congo: Mobutu and the Nihilism of Africa that Naipaul had written in 1975, has brought the novel much attention, and much criticism especially from leading African and Caribbean writers such as Chinua Achebe and Derek Walcott.

Achebe, in his essay, Impediments to Dialogue between North and South, describes Naipaul as "the modern Conrad" (28) and the novel as a "scornful work which Naipaul has written on Africa" (28). Walcott, the West Indian poet who won the Nobel prize for literature in 1992, described A Bend in the River as a "racist joke." (Conversations with Derek Walcott, 81)

In order to address the many accusations that Naipaul received in relation to A Bend in the River, a thorough analysis of the novel is crucial. Such an analysis will facilitate an understanding of Naipaul's motivation to write the novel in the first place. Was Naipaul's purpose of writing the novel to mock Africa, or was it to highlight the nihilistic issues that he believed were crippling the African society? These are the questions that this paper hopes to answer where $A$ Bend in the River is concerned. The discussion of $A$ Bend in the River will largely revolve around Salim's preoccupation with handling the nihilistic situation around him that ends up stifling his growth and success and eventually his future.

Engdahl, in his Presentation Speech for the 2001 Nobel Prize in Literature, said the following of Naipaul, "Naipaul is no worshipper of fantasy or utopia, no creator of alternative worlds. Dickens' ability to describe London with the open gaze and simplicity of a child is his declared ideal" ("Nobel Prizes").

Indeed, what Naipaul has successfully done is to paint for the reader a picture of a part of Africa that is so realistic that the reader is able to effortlessly detect the sense of futility in the novel, and the nihilistic trends that shape the country on the whole, and the existential nihilism which seems to be the preoccupation of the individuals featured in the novel. This realistic portrayal by Naipaul of Africa is reflected by Mohan in her book, The Postcolonial Situation in the Novels of V.S. Naipaul, in which views Naipaul's approach to $A$ Bend in the River as a sympathetic gesture. "In A Bend in the River, there is a considerable difference in the treatment of Africa. Not only is he more sympathetic but there is a sincere attempt on his part to analyse and arrive at an understanding of the problems that grip post-independence Africa" (Postcolonial Situation in the Novels of V.S. Naipaul, 119).

Nietzsche (1844-1900), the philosopher who is most often associated with Nihilism, wrote in The Will to Power that "every belief, every considering something true, is necessarily false because there is simply no true world." Of course, when Nietzsche said that there is 'no true world,' he did not mean that the concept of a real world does not exist; what he meant was that there is no objective order or structure to the world except that which we give it. In other words, the world achieves its objectivity based on what we make of it and it becomes meaningful only when we give it meaning, and only then does the world appear to make sense to us. Nietzsche characterised Nihilism as emptying the world and especially human existence of meaning, purpose, comprehensible truth, or essential value, and this stems from his notion that "knowledge is always by someone of something; it is always bound by perspective, and is never mere fact" (Wicks 2010).

A passage from $A$ Bend in the River offers a relevant example. Salim joins a group of expatriates at a party, and while they sit listening to a famous American singer, Joan Baez, whose songs touch on war, injustice, and oppression, he reflects,

It was make-believe-I never doubted that. You couldn't listen to sweet songs about injustice unless you expected justice and received it much of the time. You couldn't sing songs about the end of the world unless - like the other people in that room, so beautiful with such simple things: African mats on the floor and African hangings on the wall and spears and masks-you felt that the world was going on and you were safe in it. How easy it was, in that room, to make those assumptions! (A Bend in the River, 149) 


\title{
aㅛ \\ International Journal of Applied Linguistics \& English Literature \\ ISSN 2200-3592 (Print), ISSN 2200-3452 (Online)
}

Vol. 1 No. 3; July 2012 [Special Issue on World Literature in English]

Salim is one such person, who lives outside "that room" ( $A$ Bend in the River, 149); the one whose life does not offer the luxury of observing injustice from the outsider's point of view. It is easier for one who is detached from a situation to think that he can try and make meaning out of it; that ability comes with the assurance that he will remain an outsider and not be affected by that situation. The moment he experiences injustice, the entire perception of the situation alters because then he becomes the 'insider.' To the insider who suffers injustice, the act of listening to a song on injustice and appearing to appreciate it would come across as 'fake' and would not depict a true world. And so, when Salim refers to the scenario as 'make believe,' he is merely reflecting on Nietzsche's notion that "every belief, every considering something true, is necessarily false because there is simply no true world" ( $\underline{\text { Pratt}})$.

In $A$ Bend in the River, the manner in which Naipaul passionately shapes the characters of Salim and Indar suggests his "fierce passion for the individual to be free from the dead hand of the given." (Packer 2002). Both Salim and Indar are every inch the survivors that Naipaul's writings often revolve around, and they are also in some ways, a mirror image of who Naipaul was when he left Trinidad for London and refused to return home after his studies. "If I did so, I shall die from intellectual starvation," (Between Father and Son, 2001) he wrote in his letter from Oxford to his father. Naipaul chose to live in London in order to make it as a writer, and his fierce conviction in the need to emerge from trapped societies often surface in his works. According to Pratt,

when we abandon illusions, life is revealed as nothing; and for the existentialists, nothingness is the source of not only absolute freedom but also existential horror and emotional anguish. Nothingness reveals each individual as an isolated being "thrown" into an alien and unresponsive universe, barred forever from knowing why yet required to invent meaning. (Pratt)

"A Dark Vision" is how Irving Howe describes the novel in his 1979 review in The New York Times, and true enough, the events in the novel unfold as pessimistically and hopelessly as Naipaul could possibly present. A point to note here, however, is that Naipaul's novel is based on real life events - only the key characters were fictitious - all else in the story was what Naipaul saw in reality on his travels to Congo/Zaire. And so, the nihilism that permeates through the novel is reflective of the real thing. However, if one further analysed the concept of nihilism found in the novel, the aspect that would stand out would be the freedom Naipaul gave his characters to find their ways out of the nihilistic trends that they were surrounded with. It was up to the characters to find the strength within them to rise above it all, and to find meaning and their place in the world.

If one wishes to analyse the reason why Naipaul presented Africa the way he did in A Bend in the River, it would help greatly to know what Naipaul has to say about the Africans. The question if Naipaul is merely abhorrent of the Africans for racist reasons or if Naipaul felt strongly about the Africans' inadequacies is answered in an interview that he gave to Adrian Rowe-Evans in 1971 for Transition, in which he said,

When I was in east Africa recently, I was constantly hearing on every side that this was the Decade of Africa, as if Africa were suddenly going to become technically, educationally, culturally advanced, and politically powerful. I was appalled to find that people who possessed a few tiny skills were so convinced that they, simple people, were carrying the seeds of all civilization, all culture, all literature, all technology. That was rubbish...The idea that all the things which have been presented to Africa have somehow been already assimilated and appropriated by Africa, is the most hideous type of conning. It may be a willing cunning, voluntary on both sides, but it remains cunning. (Conversations with V.S. Naipaul, 24)

\begin{abstract}
Although he was appalled by the nihilistic state that he found the African country to be in, and proceeded to present it as such in A Bend in the River, it cannot be denied that Naipaul's cynicism could be driven by a deep desire for the situations to improve. The possibility of this side of Naipaul is confirmed by Kenyan novelist, Ngugi Wa Thiong'o, who upon hearing that Naipaul had won the Nobel Prize in Literature, had said, "He deserves it. V.S. Naipaul is one of the greatest writers of our times. His satiric humour has the sharpness of a surgeon's knife. Beneath the satire is a caring spirit” (Mwangi).
\end{abstract}


International Journal of Applied Linguistics \& English Literature

ISSN 2200-3592 (Print), ISSN 2200-3452 (Online)

Vol. 1 No. 3; July 2012 [Special Issue on World Literature in English]

\section{Conclusion}

Naipaul's penchant for highlighting human flaws in his writings, in this instance, in his works of fiction, can be clearly seen throughout the two novels, The Mystic Masseur and A Bend in the River. However, one can sense a difference in Naipaul's approach of doing so in the two novels, which were written 22 years apart from one another. In The Mystic Masseur, the frivolities of the characters are viewed with humour, which downplays the seriousness of the many uncertainties that the characters are faced with in their lives. The use of humour in the case of The Mystic Masseur reflects Naipaul's soft corner for Trinidad and its people, for although Naipaul had left Trinidad, the country of his birth, at the age of 18 to further his studies and never returned for good, his concern for the growth and development of Trinidad remains within him, and he probably believes that he is merely doing his part for Trinidad by pointing out its flaws through his writings. Naipaul believes that it is the role of a writer to present the real truth to readers regardless of how ugly it appears; even if it has to be done harshly, and even when the truth is not amicably accepted by readers and people in general.

Where $A$ Bend in the River is concerned, Naipaul's role is that of an observer who was merely representing the reality that he saw in the form of fiction. Here too, Naipaul's intention was probably not to undermine the Africans or the African countries, but to present the truths that he saw, as he believes a writer should. The support Naipaul has for his negative portrayal of Africans is the nihilistic setting of the African country that he witnessed during his travels to Congo/Zaire in the 1970s. A Bend in the River is, in fact, a fictional representation of one part of the African world he saw and reported of in his 1975 essay entitled A New King for the Congo: Mobutu and the Nihilism of Africa.

In both the novels, it appears as if Naipaul was merely depicting the realities that he saw during his time in both the countries, and in doing so, was merely playing the role a good writer who must tell his readers what they need to know regardless of the ugliness of it all.

\section{References}

Achebe, Chinua. Hopes and Impediments: Selected Essays. Anchor Books, 1989. Print.

Appleyard, Brian. "VS Naipaul: The Great Offender." The Sunday Times. (2007) Web. 24 Dec.

2010. http://entertainment.timesonline.co.uk/tol/arts_and_entertainment

Baer, William. Conversations with Derek Walcott. Mississippi UP, 1996. Google Book Search. Web. 15 Nov. 2010 .

Gussow, Mel. "Writer Without Roots." The New York Times. (1976) Web. 12 Oct.

2010. http://www.nytimes.com/books/98/06/07/specials/naipaul-roots.html

Howe, Irving. “A Dark Vision.” Books: The New York Times on the Web.

http://www.nytimes.com/books/98/06/07/specials/naipaul-river.html

Jussawalla, Feroza F. Conversations with V.S. Naipaul. Mississippi: Mississippi UP, 1997. Google Book Search. Web. 12 Nov. 2010.

King, Bruce. V.S. Naipaul. London: Macmillan, 1993. Print.

Mohan, Champa. Postcolonial Situation in the Novels of V.S. Naipaul. New York: Atlantic, 2004. Google Book Search. Web. 12 March. 2011.

Mwangi, Evan. “A Nobel Prize for Cynic Naipaul.” Sunday Nation - Lifestyle. 2001. Web. 20 Dec. 2010. http://www.aluka.org/action/showMetadata?doi=10.5555/AL.CC.DOCUMENT.KIPC01807

Naipaul, V.S. A Bend in the River. London: Picador, 2002. Print.

---. The Middle Passage. New York: Penguin Books, 2001. Print.

---. The Mystic Masseur. New York: Penguin Books, 1964. Print.

---. The Writer and the World (Essays). London: Picador, 2002. Print.

---. A Writer's People: Ways of Looking and Feeling. Knopf, 2008. Print.

---. Between Father and Son: Family Letters. London: Vintage Books, 2001. Google Book Search. Web. 12 Nov. 2010. 
International Journal of Applied Linguistics \& English Literature

ISSN 2200-3592 (Print), ISSN 2200-3452 (Online)

Vol. 1 No. 3; July 2012 [Special Issue on World Literature in English]

Ormerod, David. "In a Derelict Land: The Novels of V. S. Naipaul." Contemporary Literature 9.1 (1968):

74-90. JSTOR. Web. 14 Dec. 2010.

Packer, George. "V.S. Naipaul's Pursuit of Happiness.” Summer 2002. Dissent. Web. 24 Dec. 2010. < http://www.dissentmagazine.org/article/?article=590>.

Pratt, Alan. "Nihilism." 1 Dec 1999. Internet Encyclopaedia of Philosophy. Web. 14 Nov.

2010. <http://www.utm.edu/research/iep/n/nihilism.html/>.

Sudan, Richard. "V.S. Naipaul Does Trinidad a Disservice.” guardian.co.uk (2011) Web. 20 March

2011. <http://www.guardian.co.uk/commentisfree/2011/feb/10/

vs-naipaul-trinidad-racial-divide/>.

"The Nobel Prizes". Nobelprize.org. 21 Apr 2011. http://nobelprize.org/nobel_prizes/

literature/laureates/2001/presentation-speech.html

Thieme, John. "Searching for a Centre: The Writing of V.S. Naipaul." Third World Quarterly 9.4 (1987):

1352-65. JSTOR. Web. 26 Dec. 2010.

Wicks, Robert, "Friedrich Nietzsche", The Stanford Encyclopedia of Philosophy Web. 14 Mar.

2011. <http://plato.stanford.edu/archives/sum2010/entries/nietzsche/>.

\section{Indrani Ramachandran}

Indrani is currently pursuing her postgraduate studies in Universiti Putra Malaysia. She is also the publication manager of Hospice Malaysia.

\section{Rohimmi Noor}

Rohimmi is a lecturer at the Faculty of Modern Languages and Communication, Universiti Putra Malaysia. His research interest includes postcolonial literature, modernist writers, and literary criticism. 